\title{
Diversity and Distribution of Culturable Thermus Species in Terrestrial Hot Springs of Southwestern Yunnan Province in China
}

\author{
Yongxia Wang ${ }^{1}$, Canhai Xu ${ }^{1}$, Long Han ${ }^{1}$, Chengpeng $\mathrm{Li}^{1}$, Wei Xiao ${ }^{1}$ and Xiaolong Cui ${ }^{1,2, *}$ \\ 1 Yunnan Institute of Microbiology, School of Life Sciences, Yunnan University, Kunming 650091, China; \\ wangyx@ynu.edu.cn (Y.W.); canhaix@mail.ynu.edu.cn (C.X.); biooracle@foxmail.com (L.H.); \\ cpli@mail.ynu.edu.cn (C.L.); xiaow313@aliyun.com (W.X.) \\ 2 State Key Laboratory for Conservation and Utilization of Bio-Resources in Yunnan, Yunnan University, \\ Kunming 650091, China \\ * Correspondence: xlcuiynu@aliyun.com
}

check for updates

Citation: Wang, Y.; Xu, C.; Han, L.; Li, C.; Xiao, W.; Cui, X. Diversity and Distribution of Culturable Thermus Species in Terrestrial Hot Springs of Southwestern Yunnan Province in China. Diversity 2021, 13, 455. https://doi.org/10.3390/d13090455

Academic Editor: Michael Wink

Received: 11 August 2021

Accepted: 16 September 2021

Published: 21 September 2021

Publisher's Note: MDPI stays neutral with regard to jurisdictional claims in published maps and institutional affiliations.

Copyright: (c) 2021 by the authors. Licensee MDPI, Basel, Switzerland. This article is an open access article distributed under the terms and conditions of the Creative Commons Attribution (CC BY) license (https:// creativecommons.org/licenses/by/ $4.0 /)$.

\begin{abstract}
The Yunnan geothermal area has many neutral and alkalescent thermal springs. Members of the genus Thermus have been found in thermal environments. In this study, we attempted to cultivate numerically abundant Thermus species using a variety of different strategies. A total of 223 strains of Thermus-like bacteria were isolated from seventeen hot spring samples of four geothermal regions (Baoshan, Dali, Lincang and Dehong). These strains were classified into two genera, Thermus and Meiothermus, based on $16 \mathrm{~S}$ rDNA. The optimal isolation temperature of the Thermus genus was $63-70{ }^{\circ} \mathrm{C}$. The highest Thermus diversity was found at $63{ }^{\circ} \mathrm{C}$. Thermus brockianus was a universal culturable bacterium in the four geothermal regions. The principal component analysis (PCA) showed that T. oshimai preferred to inhabit the hot springs of the Baoshan (Bs) geothermal region, and T. amyloliquefaciens dominated the Dali (Dl) geothermal region, whereas T. tengchongensis accumulated in the Lincang $(\mathrm{Lc})$ and Dehong $(\mathrm{Dh})$ geothermal regions. The results suggested that Thermus species had habitat-preferable characteristics among the four geothermal regions. The findings may help identify the niche from which Thermus strains can likely be isolated.
\end{abstract}

Keywords: cultivation-dependent method; geothermal region; thermal spring; Thermus diversity

\section{Introduction}

Yunnan Province, one of China's best-known volcanic geothermal areas, is located in southwestern China. It is located at the collision boundary between the Indian and Eurasian plates and is an integral part of the Mediterranean-Himalayan geothermal belt. As a result of post-volcanism and an active geothermal system, there are many neutral and alkalescent thermal springs in this area. These thermal springs are mainly located in Tengchong County in the Baoshan region, Eryuan County in the Dali region, Yun County in the Lincang region and Lianghe County in the Dehong region of Yunnan Province. Of these, Tengchong springs have been extensively studied by microbiologists using cultivationindependent approaches [1-9] and cultivation-dependent methods [10-18]. For the other geothermal systems, with the exception of a few surveys $[19,20]$, many thermal springs in the Yunnan geothermal area have not yet been studied in detail.

Since Brock et al. [21] isolated and named the extreme thermophile Thermus aquaticus from Yellowstone National Park, many strains of Thermus have been isolated from neutral to alkaline thermal environments around the world [22]. However, only 18 (scientific) names are valid species because most isolates are phylogenetically closely related (https:/ / lpsn.dsmz.de/genus/thermus, accessed on 10 September 2021). Out of 18 Thermus species, 16 species, including T. brockianus, T. thermophiles, T. oshimai, T. caliditerrae, T. arciformis, T. islandicus, T. igniterrae, T. antranikianii, T. tengchongensis, T. amyloliquefaciens, T. caldilimi, T. aquaticus, T. caldifontis, T. filiformis, T. profundus and T. tenuipuniceus have been found in 
hot springs around the globe, among the other two species, T. composti was isolated from an oyster mushroom compost, and T. scotoductus was isolated from a South African gold mine. The typical characteristics of the genus Thermus are Gram-stain-negative, aerobic and rod-shaped. Most species form yellow colonies and grow optimally at $60-70{ }^{\circ} \mathrm{C}$. Several Thermus species have shown biotechnological potential, such as enzymes from Thermus aquaticus and T. thermophilus, which have exhibited higher activity and stability than synthetic or enzymes from mesophilic organisms [23,24]. Reduction of heavy metals from T. scotoductus, which is essential for the removal of heavy metal pollution and the removing of organic contaminants in water [25,26].

Over 50 strains identified as Thermus have been isolated from hot springs in Tengchong [27-29]. However, most of these Thermus strains have remained unclassified, or some were identified as 'Thermus rehai', but the name is not validly published. A few studies have reported the isolation and diversity of the genus Thermus from hot springs in Yunnan Province, southwestern China. To further understand the diversity and distribution of Thermus species in Yunnan province, southwestern China, we attempted to cultivate numerically abundant species using a variety of different strategies. Enrichment conditions (various temperatures and media) were designed to favor the recovery of species adapted to the temperatures and substrates. In the course of this work, we isolated and characterized Thermus strains, and our results reveal the diversity of Thermus isolates within one region or between regions whose distribution may be controlled by specialized adaptation to environmental features.

\section{Materials and Methods}

\subsection{Sampling Area and Sample Collection}

Seventeen hot springs and effluent channel samples were collected from ten hot springs and examined based on contrasting characteristics, such as $\mathrm{pH}$, temperature and location in four geothermal regions (Lincang region (Lc), Baoshan region (Bs), Dali region (Dl) and Dehong region (Dh)) of western Yunnan Province, southwestern China. These hot springs have not been developed, and most of them are in farmers' homes. So, these hot springs have been named; here we give a number for a hot spring. The temperature and $\mathrm{pH}$ of the hot springs or effluent channels were recorded at the time of sampling (Table 1). Water, sediment and microbial mat samples were collected from each hot spring, and then the samples were aseptically transferred to sterilized $250 \mathrm{~mL}$ Erlenmeyer flasks, stored at room temperature and processed within a few hours before examination in the laboratory.

\subsection{Thermus Strain Isolation and Culture Conditions}

Three media were used to isolate Thermus strains from the hot spring samples: (1) Castenholz medium (DSMZ medium 86), (2) Thermus 162 medium (DSMZ medium 878) and (3) Thermus rubber medium (DSMZ medium 256). The above media were adjusted to different $\mathrm{pH}$ values ( $\mathrm{pH} 7.0-8.5$ ) according to the $\mathrm{pH}$ of the hot spring samples (Table 1). A series of dilution isolation methods was used: first, samples (water, sediment and microbial mats) from the same hot spring were mixed thoroughly for $1 \mathrm{~h}$, and then the mixed samples $(5 \mathrm{~g})$ were blended with sterile water $(45 \mathrm{~mL})$ for $2 \mathrm{~min}$, followed by five serial dilutions with sterilized water. Amounts of $200 \mu \mathrm{L}$ of the $10^{-3}, 10^{-4}$ and $10^{-5}$ dilutions of each sample were spread on the surface of the 3 solid media. All plates were incubated at different temperatures $\left(50,55,63,70,75^{\circ} \mathrm{C}\right)$ for 2 to 4 days (Table 1$)$. Due to most strains of genes Thermus being yellow-pigmented, colonies that showed cultural characteristics of this genus were counted, as well as colonies of other bacteria. During this period, the plates were checked daily for the presence of Thermus-like strain colonies. Thermus-like strains were picked out and purified on Castenholz medium plates at $55^{\circ} \mathrm{C}$ and were then transferred to Castenholz medium slants for storage at $4{ }^{\circ} \mathrm{C}$.

\subsection{DNA Extraction and PCR Amplifications}

Complete genomic DNA was extracted as described by Cui et al. [30] with some modifications. Approximately $50 \mathrm{mg}$ of biomass collected by scraping cells from the Castenholz 
medium plates was incubated for $1 \mathrm{~h}$ at $37^{\circ} \mathrm{C}$ in $480 \mu \mathrm{L}$ TE extraction buffer ( $\mathrm{pH}$ 8.0; $10 \mathrm{mM}$ Tris-HCl, $1 \mathrm{mM}$ EDTA) and $20 \mu \mathrm{L}$ lysozyme $(50 \mathrm{mg} / \mathrm{mL}$; Biosharp, Guangzhou, China). Then, $50 \mu \mathrm{L}$ SDS $(20 \%, w / v$; Tiandz, Beijing, China) and $5 \mu \mathrm{L}$ protease $\mathrm{K}(20 \mu \mathrm{g} / \mathrm{mL}$; BioFroxx, Guangzhou, China) were added for further incubation for $1 \mathrm{~h}$ at $55^{\circ} \mathrm{C}$. Subsequently, the lysate was extracted with a phenol-chloroform-isoamyl alcohol solution (25:24:1; Tiandz), and DNA was recovered by sodium acetate and isopropanol precipitation. The pellet was washed with $70 \%(v / v)$ ethanol, dried under vacuum and resuspended in $50 \mu \mathrm{L}$ TE buffer (pH 8.0; $10 \mathrm{mM}$ Tris-HCl, $1 \mathrm{mM}$ EDTA). Genomic DNA was stored at $-20^{\circ} \mathrm{C}$.

Table 1. The sample characteristics and isolation conditions of the four geothermal regions of southwestern Yunnan Province. /, Not data available.

\begin{tabular}{|c|c|c|c|c|c|c|}
\hline $\begin{array}{l}\text { Geothermal } \\
\text { Region }\end{array}$ & Hot Spring & Sample & $\begin{array}{c}\text { Sample } \\
\text { Temperture }\left({ }^{\circ} \mathrm{C}\right)\end{array}$ & Sample pH & $\begin{array}{c}\text { Isolation } \\
\text { Temperature }\left({ }^{\circ} \mathrm{C}\right)\end{array}$ & Isolation $\mathrm{pH}$ \\
\hline \multirow{5}{*}{ Lincang (Lc) } & 4 & $4-1$ & 75.3 & 6.92 & \multirow{5}{*}{$50,55,63,70,75$} & 7.0 \\
\hline & & $5-1$ & / & / & & \\
\hline & 5 & $5-2$ & 91.5 & 9.20 & & 8.5 \\
\hline & & $5-3$ & / & / & & \\
\hline & 6 & $6-1$ & 93.0 & 8.17 & & 8.0 \\
\hline \multirow{5}{*}{ Baoshan (Bs) } & $8 \mathrm{~A}$ & $8-1$ & 79.9 & 6.34 & \multirow[t]{2}{*}{$50,55,63,70,75$} & \multirow[t]{2}{*}{7.0} \\
\hline & \multirow{3}{*}{$8 \mathrm{~B}$} & $8-2$ & / & / & & \\
\hline & & $8-3$ & 54.8 & 6.90 & \multirow[t]{2}{*}{50,55} & \multirow[t]{2}{*}{7.0} \\
\hline & & $8-4$ & / & / & & \\
\hline & $8 C$ & $8-5$ & 72.7 & 6.62 & $50,55,63,70$ & 7.0 \\
\hline \multirow{5}{*}{ Dali (Dl) } & 16 & $16-1$ & 56.9 & 7.21 & \multirow{4}{*}{$50,55,63,70$} & \multirow{4}{*}{7.0} \\
\hline & & $17-1$ & 71.1 & 6.48 & & \\
\hline & $17 \mathrm{~A}$ & $17-2$ & 74.8 & 6.63 & & \\
\hline & & $17-3$ & / & / & & \\
\hline & 18 & $18-1$ & 75.0 & 6.64 & $50,55,63,70,75$ & 7.0 \\
\hline \multirow{2}{*}{ Dehong (Dh) } & \multirow{2}{*}{13} & $13-1$ & 79.4 & 7.92 & \multirow{2}{*}{$50,55,63,70,75$} & \multirow{2}{*}{8.0} \\
\hline & & $13-2$ & / & / & & \\
\hline
\end{tabular}

The $16 \mathrm{~S}$ rRNA genes were amplified as described by Cui et al. [30] with a Perkin-Elmer 2400 thermal cycler (Perkin-Elmer Cetus Co., Norwalk, CT, USA); 27F (5'-AGAGTTTGA TCMTGGCTCAG-3') and 1492R (5'-TACGGYTACCTTGTTACGACTT-3') primers [31] were used. The amplification program consisted of pre-denaturation at $95^{\circ} \mathrm{C}, 4 \mathrm{~min}$; 30 cycles at $95^{\circ} \mathrm{C}, 30 \mathrm{sec} ; 56^{\circ} \mathrm{C}, 30 \mathrm{sec}$ and $72{ }^{\circ} \mathrm{C}, 1 \mathrm{~min}$ and $30 \mathrm{sec}$; and a final extension at $72{ }^{\circ} \mathrm{C}$ for $5 \mathrm{~min}$. The final products were analyzed by electrophoresis on $1 \%$ agarose, and the molecular weights of amplified DNA were estimated by comparison with the E. coli $\lambda \mathrm{T} 14$ (TaKaRa, Kusatsu, Japan) DNA ladder.

\subsection{Sequence Classification and Phylogenetic Analysis}

The sequencing of PCR products was performed using single-pass Sanger sequencing with primer 27F on an Applied Biosystems DNA sequencer (model $3730 \mathrm{XL}$ ), and the length of all sequences exceeded $700 \mathrm{bp}$. The $16 \mathrm{~S}$ rRNA gene sequences were compared within the NCBI database (http:/ / www.ncbi.nlm.nih.gov/Blast (accessed on 17 April 2020) using the Basic Local Alignment Search Tool (BLAST) to determine the relative phylogenetic positions. Phylogenetic analysis was conducted using MEGA 6.0 [32] by first generating a complete alignment of $16 \mathrm{~S}$ rRNA gene sequences of the isolates and type strains of all validly published species within the gene Thermus. Dendrograms were generated from $K_{n u c}$ values [33] using the neighbor-joining (NJ) method of Saitou and Nei [34], and bootstrapping was carried out using 1000 replications. The $16 \mathrm{~S}$ rRNA sequences from the representative strains in different species were deposited in GenBank under accession numbers MH827613 to MH827835. 


\subsection{OTU Assignment and Community Analysis}

All good-quality sequences were aligned with CLUSTALX 1.83 [35] and were assigned to operational taxonomic units (OTUs) based on a cutoff value of 0.03 using DOTUR software [36]. The OTU-based similarity or dissimilarity between the culturable communities in 4 geothermal regions was calculated by "SIMPER" analysis using PAST software $[37,38]$. The contributions of the OTUs to the similarity or dissimilarity were calculated based on the relative abundances of OTUs between the groups. Clustering trees and principal component analysis (PCA) plots were created between the samples based on the average Bray-Curtis similarity of OTU compositions in the different geothermal regions.

\section{Results}

\subsection{Screening of the Culturable Thermus-Like Strains from the Four Geothermal Regions}

A total of 17 samples from 10 hot springs, including hot spring water, sediment and microbial mats, were collected from four geothermal regions in August 2011. These hot springs exhibited heterogeneity with regard to temperature, $\mathrm{pH}$ and conductivity. The temperature at the sampling sites varied from 54 to $93{ }^{\circ} \mathrm{C}$, the $\mathrm{pH}$ from 6.3 to 9.2 and the conductivity from 563 to $2756 \mu \mathrm{s} / \mathrm{cm}$ (Lc: $75-93{ }^{\circ} \mathrm{C}, \mathrm{pH} 6.9-9.2,659-2756 \mu \mathrm{s} / \mathrm{cm}$, Bs: $54-80^{\circ} \mathrm{C}, \mathrm{pH} 6.3-6.9,1106-1164 \mu \mathrm{s} / \mathrm{cm}$; Dl: $71-75^{\circ} \mathrm{C}, \mathrm{pH} 6.4-7.2,1459-1534 \mu \mathrm{s} / \mathrm{cm}$; Dh: $79{ }^{\circ} \mathrm{C}, \mathrm{pH} 7.92,578 \mu \mathrm{s} / \mathrm{cm}$ ) (Table 1). After the screening, with the exception of 23 Meiothermus strains, a total of 200 strains of Thermus were obtained from the 17 hot spring samples using three different media, and 30 to 80 strains were obtained from each geothermal region (Table 2). An OTU-based analysis of the 16S rRNA gene was conducted. At a $3 \%$ cutoff, which is generally considered the label for species, a total of 11 OTUs were obtained (Supplementary Table S1). The classification of the OTUs against the NCBI and RDP 16S rRNA reference databases is shown in Table 2.

\subsection{Species of Culturable Thermus-Like Bacteria in the Lincang Geothermal Region}

Among the 11 OTUs, eight OTUs were isolated from the Lc geothermal region, seven OTUs were isolated from the Bs geothermal region, five OTUs were isolated from the $\mathrm{Dh}$ geothermal region and four OTUs were isolated from the Dl geothermal region (Figure 1 and Supplementary Table S1). Consequently, the community structure was studied specifically in the four geothermal regions.
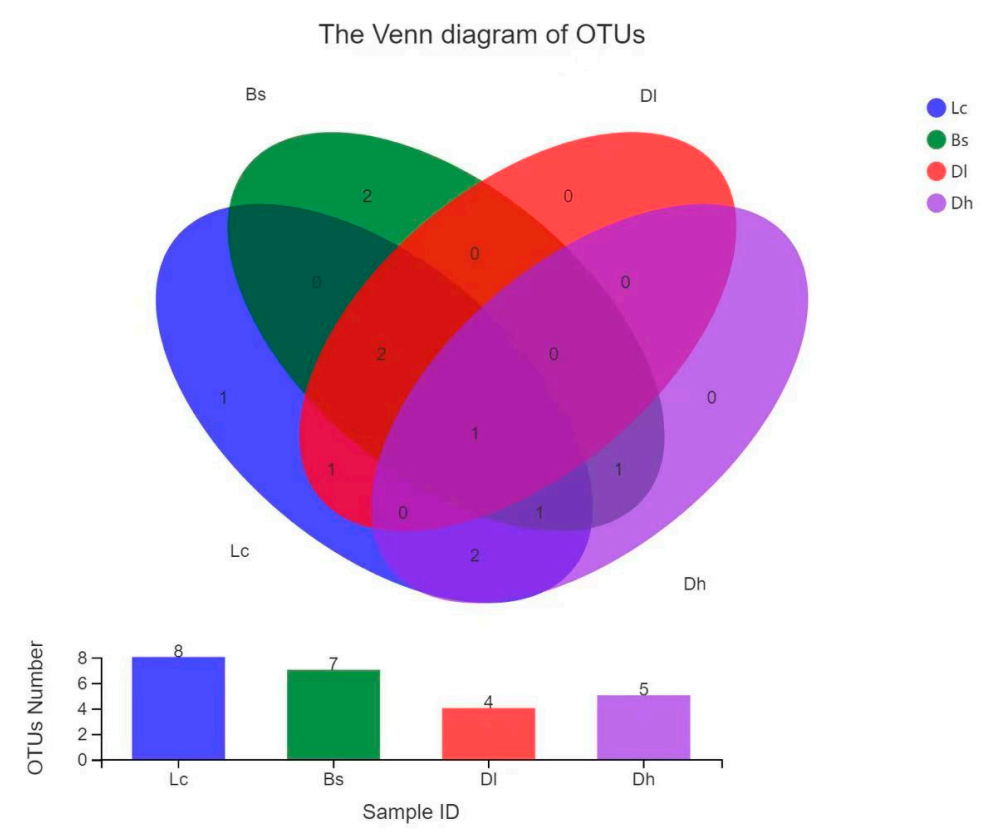

Figure 1. Venn diagram of OTUs at a cutoff of 0.03 for the Thermus-like bacteria in four geothermal regions. The numbers in the overlapping parts represent the shared OTUs among different regions. 
Table 2. Distribution characteristics of Thermus-like strains from different hot springs of four geothermal regions of southwestern Yunnan Province.

\begin{tabular}{|c|c|c|c|c|c|c|c|c|c|c|c|c|c|c|c|c|}
\hline \multirow{2}{*}{ OTU } & \multirow{2}{*}{ Taxon } & \multicolumn{10}{|c|}{ Hot Spring/Hot Spring Temperature $\left({ }^{\circ} \mathrm{C}\right)$} & \multicolumn{5}{|c|}{ Isolaton Temperature $\left({ }^{\circ} \mathrm{C}\right)$} \\
\hline & & $4 / 75.3$ & $5 / 91.5$ & $6 / 93.0$ & $8 \mathrm{~A} / 79.9$ & $8 B / 54.4$ & $8 \mathrm{C} / 72.7$ & $16 / 56.9$ & 17A/75.3 & 18/71.1 & 13/79.0 & 50 & 55 & 63 & 70 & 75 \\
\hline OTU1 & T. oshimai & 2 & 1 & 10 & 10 & 5 & 16 & & 1 & & & & 7 & 14 & 19 & 5 \\
\hline OTU2 & T. brockianus & 4 & 7 & & 6 & 1 & 2 & & 1 & 12 & 1 & & 3 & 6 & 13 & 12 \\
\hline OTU3 & T. igniterrae & & & 5 & & & & & & & 8 & & 3 & 3 & 5 & 2 \\
\hline OTU4 & T. amyloliquefaciens & 1 & & 2 & & & & & 13 & 17 & & & 4 & 13 & 9 & 7 \\
\hline OTU5 & T. arciformis & & 1 & & & & 3 & & & & 1 & & 1 & 2 & 2 & \\
\hline OTU6 & T. tengchongensis & 6 & 14 & 10 & & & & & & & 19 & & 5 & 13 & 16 & 15 \\
\hline OTU7 & T. caliditerrae & & & & 2 & & 1 & & & & 1 & & 1 & 3 & & \\
\hline OTU8 & T. sp.1 & & 9 & 7 & & & & & & & & & 2 & 4 & 8 & 2 \\
\hline OTU9 & T. sp.2 & & & & & 1 & & & & & & & & 1 & & \\
\hline OTU10 & Meio. nypogaeus & & & & & & 1 & & & & & & & 1 & & \\
\hline OTU11 & Meio. ruber & & & 1 & 20 & & & 1 & & & & 7 & 7 & 8 & & \\
\hline \multicolumn{2}{|c|}{ Total mumber } & 13 & 32 & 35 & 38 & 7 & 23 & 1 & 15 & 29 & 30 & 7 & 33 & 68 & 72 & 43 \\
\hline
\end{tabular}


In the Lc geothermal region samples, eight OTUs composed of a group of 80 strains of Thermus-like bacteria were isolated and screened using three Thermus media and five temperature conditions. After sequence assignment against the NCBI and RDP databases, they were clustered into two genera of the family Thermaceae, i.e., Thermus and Meiothermus (Figure 2 and Table 2). In the genus Thermus, Thermus tengchongensis was the most abundant culturable species, which was composed of 30 strains, followed by 16 strains of unclassified Thermus sp., 13 strains of T. oshimai, 11 strains of T. brockianus, 5 strains of T. igniterrae, 3 strains of T. amyloliquefaciens and 1 strain of T. arciformis. In addition, one strain was isolated and classified into the genus Meiothermus in the hot spring samples of this geothermal region.

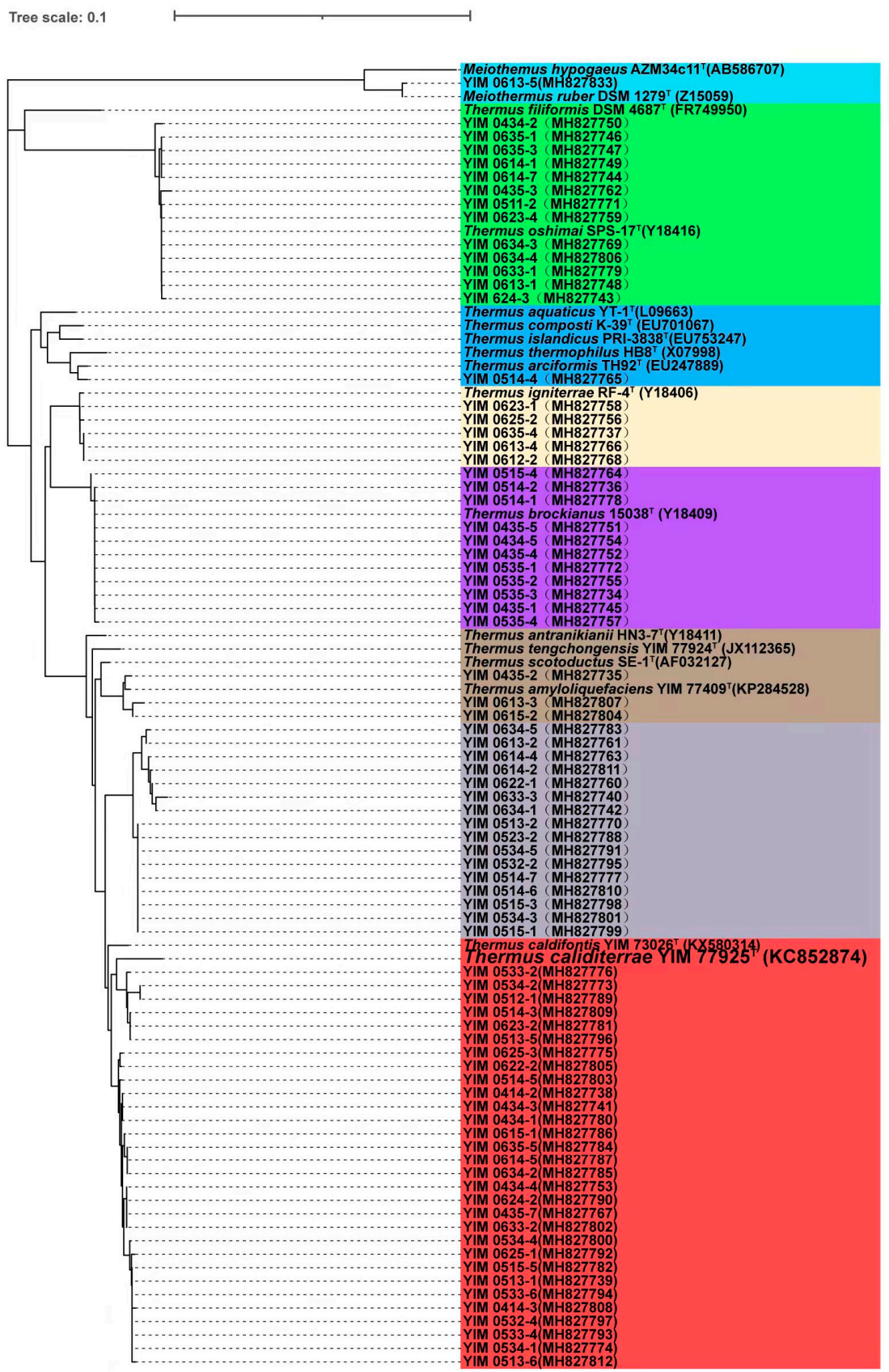

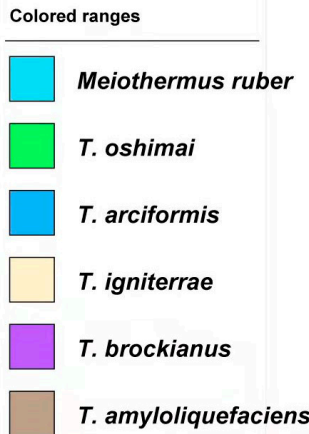

Thermus sp.

T. tengchongensis

Figure 2. The phylogenetic tree for the culturable Thermus strains in the Lincang geothermal region. Numbers at nodes indicate bootstrap values $(>50 \%$ ) based on a neighbor-joining analysis of 1000 resampled datasets. The vertical scale bar in the middle represents 0.1 substitutions per nucleotide position. 


\subsection{Species of Culturable Thermus-Like Bacteria in the Baoshan Geothermal Region}

In the Bs geothermal region samples, seven OTUs composed of a group of 68 strains of Thermus-like bacteria were isolated and screened using three Thermus media and five temperature conditions. After sequence assignment against the NCBI and RDP databases, they were clustered into two genera of the family Thermaceae, i.e., Thermus and Meiothermus (Figure 3 and Table 2). In the genus Thermus, Thermus oshimai was the most abundant culturable species in this geothermal region, which was composed of 31 strains, followed by 9 strains of T. brockianus, 3 strains of T. arciformis, 3 strains of T. caliditerrae and 1 strain of an unclassified Thermus sp. Another 21 strains were affiliated with 2 species of the genus Meiothermus, 20 strains were affiliated with Meiothermus ruber, and the last 1 belonged to Meiothermus hypogaeus.

Tree scale: 0.1

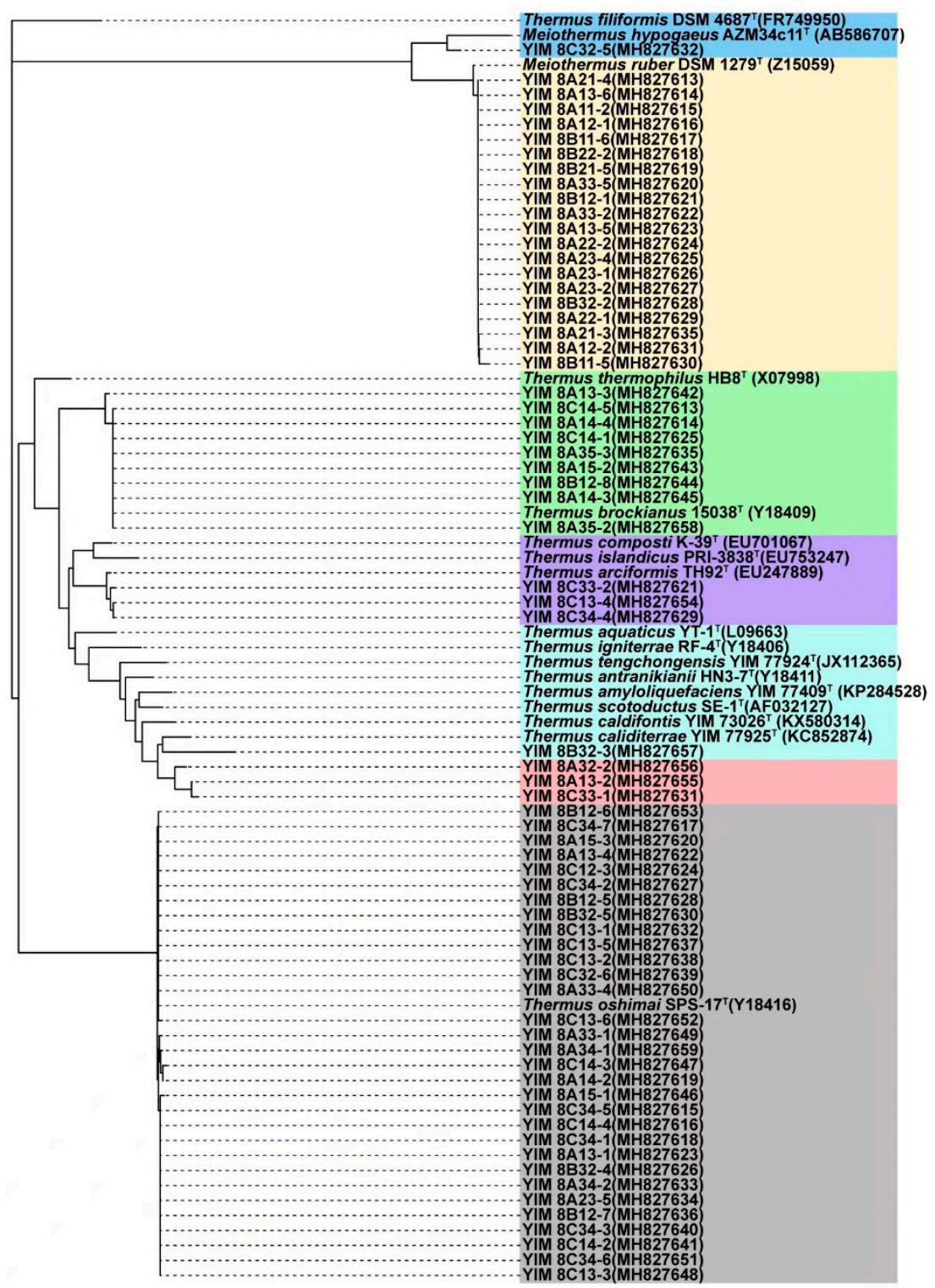

Colored ranges

Meiothermus hypogaeus

Meiothermus ruber

T. brockianus

T. caliditerrae

T. arciformis

Thermus.sp

T. oshimai

Figure 3. The phylogenetic tree for the culturable Thermus strains in the Baoshan geothermal region. Numbers at nodes indicate bootstrap values $(>50 \%$ ) based on a neighbor-joining analysis of 1000 resampled datasets. The vertical scale bar in the middle represents 0.1 substitutions per nucleotide position. 


\subsection{Species of Culturable Thermus-Like Bacteria in the Dali Geothermal Region}

From the Dl geothermal region, four OTUs, composed of a group of 45 strains of Thermus-like bacteria, were isolated from hot spring water and sediment collected in this geothermal region and were screened using three Thermus media and four temperature conditions (Figure 4 and Table 2). After the sequence assignment against the NCBI and RDP databases, two genera of the family Thermaceae were assigned, i.e., Thermus and Meiothermus (Figure 4). Thermus amyloliquefaciens was the predominant culturable Thermus species, containing 30 strains. In addition, 13 strains of T. brockianus and 1 strain of T. oshimai were also detected. Another strain belonged to Meiothermus ruber.
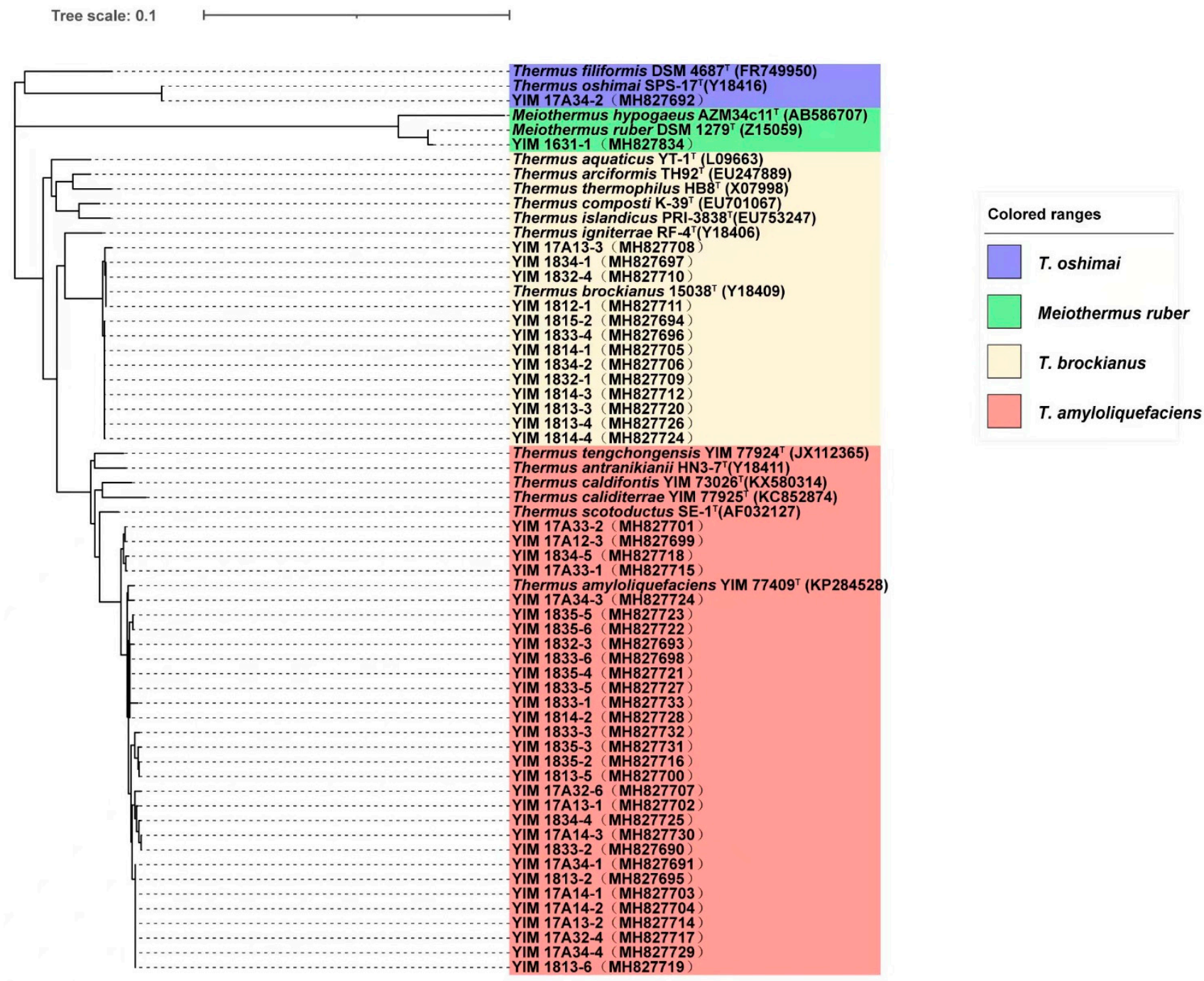

Figure 4. The phylogenetic tree for the culturable Thermus strains in the Dali geothermal region. Numbers at nodes indicate bootstrap values $(>50 \%$ ) based on a neighbor-joining analysis of 1000 resampled datasets. The vertical scale bar in the middle represents 0.1 substitutions per nucleotide position.

\subsection{Species of Culturable Thermus-Like Bacteria in the Dehong Geothermal Region}

In this study, five OTUs, composed of a group of 30 strains of Thermus-like bacteria, were detected from hot spring water and sediment collected in this geothermal region and screened using three Thermus media and five temperature conditions (Figure 5 and Table 2). After sequence assignment against the NCBI and RDP databases, 30 strains were assigned to the genus Thermus (Figure 5). Thermus tengchongensis was the predominant culturable species, containing 19 strains. Eight strains of T. igniterrae, one strain of T. brockianus, one strain of $T$. arciformis and one strain of T. caliditerrae were also detected. 


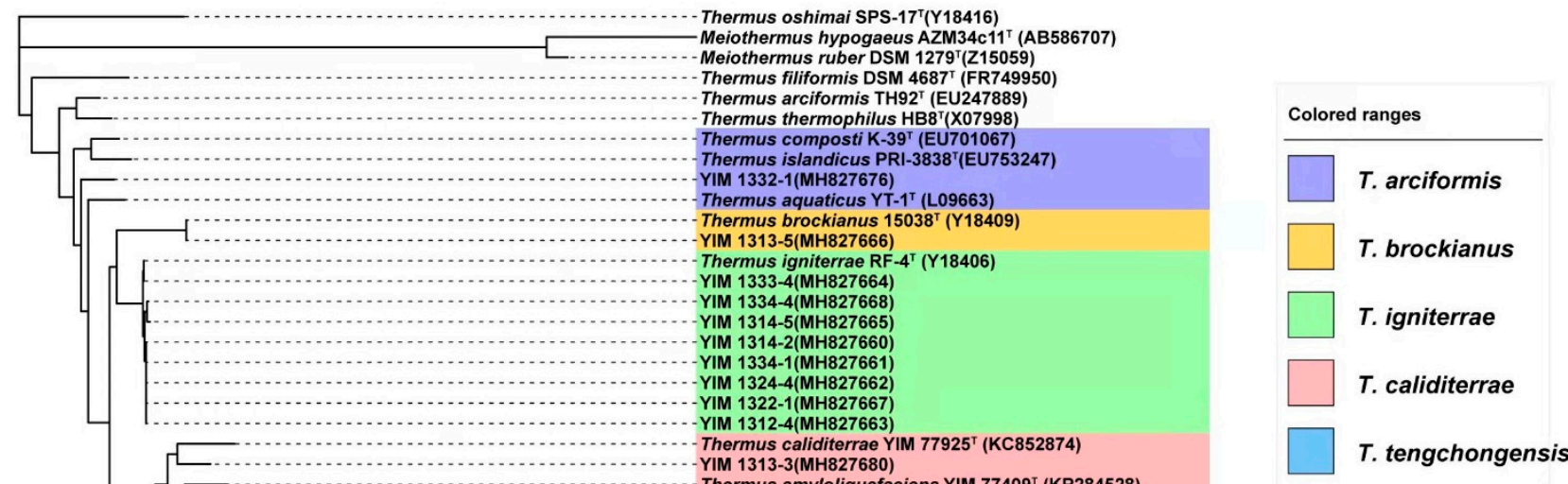

Figure 5. The phylogenetic tree for the culturable Thermus strains in the Dehong geothermal region. Numbers at nodes indicate bootstrap values $(>50 \%)$ based on a neighbor-joining analysis of 1000 resampled datasets. The vertical scale bar in the middle represents 0.1 substitutions per nucleotide position.

\subsection{Distribution of Culturable Thermus-Like Bacteria in the Four Geothermal Regions}

To compare the habitat preference of the culturable Thermus-like bacteria, the betadiversity of these bacteria was studied between the four geothermal regions in southwestern Yunnan Province. Samples from the hot springs in the Lc and Bs, Dl, and Dh geothermal regions shared the highest number of OTUs (four OTUs), in comparison with the Bs and $\mathrm{Dl}$ hot springs (three OTUs), Bs and Dh hot springs (three OTUs) and Dl and Dh hot springs (one OTU) (Figure 1). Only one OTU was shared among all four regional hot spring samples, which was OTU 1 (T. brockianus). Figure 6 shows that Thermus-like bacteria in the four regional samples could be clustered into five groups based on OTU composition. The culturable Thermus-like bacteria had low similarity in the four geothermal regions. Thermus species of the hot springs in the Lc geothermal region had a relatively closer relationship ( $24 \%$ Bray-Curtis similarity) with the Thermus-like bacteria of the hot springs in the Bs geothermal region. Based on SIMPER analysis in PAST, OTU 6 (T. tengchongensis) contributed most to the Bray-Curtis dissimilarity (22.8\% contribution), followed by T. oshimai ( $19.9 \%$ contribution), T. amyloliquefaciens ( $16.3 \%$ contribution) and T. brockianus ( $11.8 \%$ contribution), which together contributed $70.8 \%$ of the Bray-Curtis dissimilarity. This implied that these species might have habitat preferences in the hot springs of the four geothermal regions.

The PCA plot indicated that OTU 1 (T. oshimai) and OTU 11 (Meio. ruber) preferred to inhabit the hot springs of the Bs geothermal region rather than the hot springs of the Lc, Dh and Dl geothermal regions (Figure 7). For example, OTU 1 (T. oshimai) accounted for $16.3 \%$ and $2.2 \%$ of the culturable Thermus-like bacteria in the Lc and $\mathrm{Dl}$ hot springs, respectively, but no strains of OTU 1 were isolated from the Dh hot springs (Table 2). OTU 3 (T. igniterrae) and OTU 6 (T. tengchongensis) contributed most to the dissimilarity between 
the Lc and Dh geothermal regions and the two other geothermal regions. Specifically, OTU 8 (unclassified Thermus) was only isolated from hot springs in the Lc geothermal region and had a relative abundance of $20 \%$ in this region (Table 2). In the Dl geothermal region, OTU 2 (T. brockianus) and OTU 4 (T. amyloliquefaciens) contributed most to the dissimilarity between this geothermal region and the three other geothermal regions (Figure 7). In particular, OTU 4 (T. amyloliquefaciens) was the most abundant culturable Thermus strain, accounting for $66.7 \%$ of Thermus strains in this geothermal region. However, a lower abundance (3.8\%) was detected in the Lc geothermal region (Table 2), and no strains were obtained from the two other geothermal regions. OTU 2, which was the only OTU among all four regional hot spring samples, was the second most abundant culturable Thermus strains and accounted for $28.9 \%$ of the relative abundance. In addition, OTU 9 (unclassified Thermus) and OTU 11 (Meiothermus hypogaeus) were only isolated from the BS geothermal region, and both had a relative abundance of $2.9 \%$. The culturable Thermus strains presented $65 \%$ dissimilarity among the hot springs of the four geothermal regions.

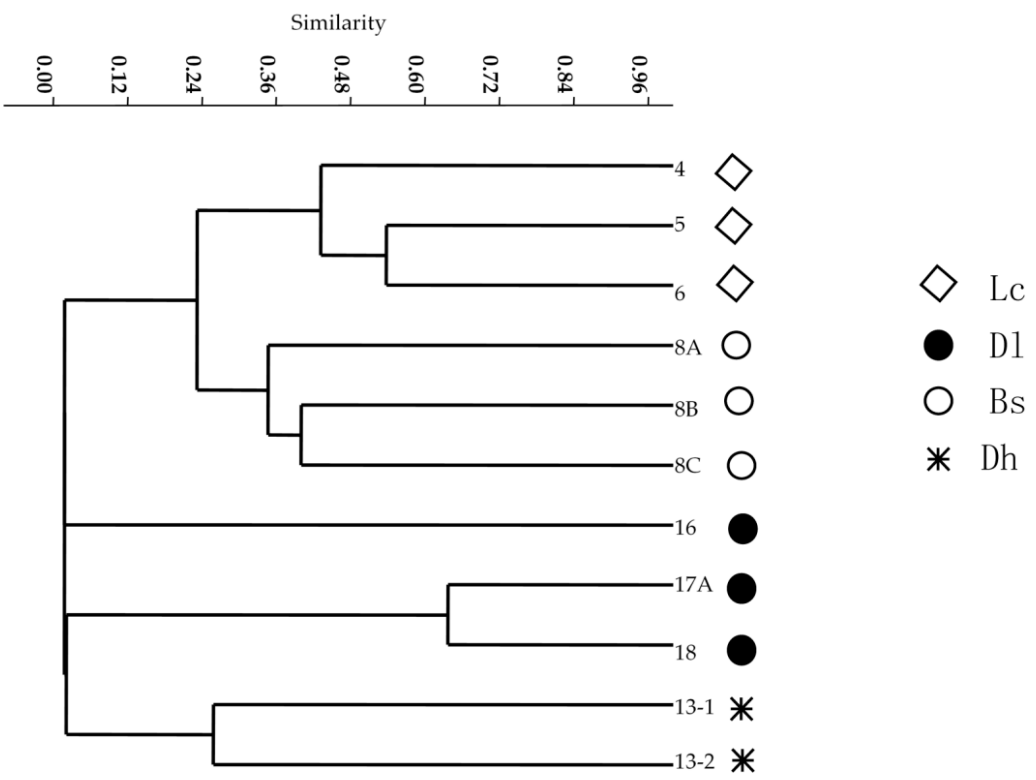

Figure 6. Cluster analyses of the culturable Thermus-like bacterial community structure in the hot springs of four geothermal regions based on Bray-Curtis similarity.

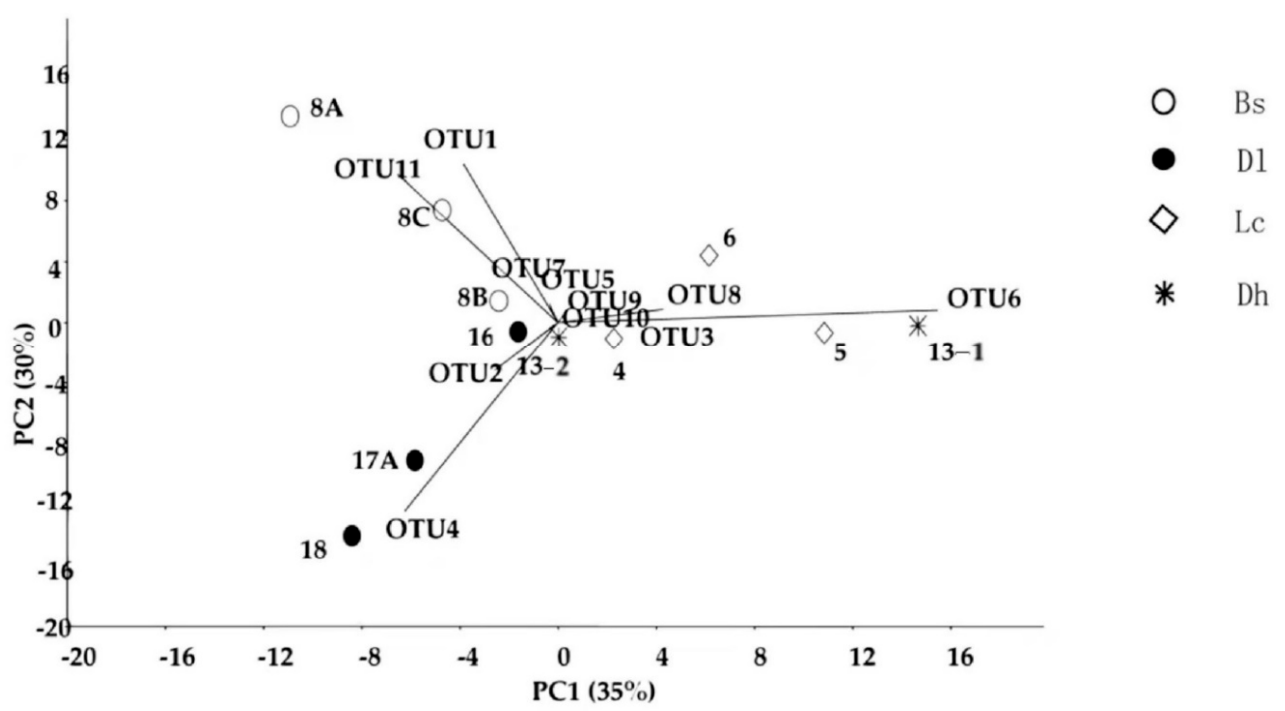

Figure 7. The PCA biplot and dominant OTUs corresponding to the dissimilarity of Thermus-like species in the hot springs among the four geothermal regions. 


\section{Discussion}

In this study, the highest Thermus diversity was found at $63{ }^{\circ} \mathrm{C}$, and under this isolation temperature, nine OTUs were detected (Table 2). This conclusion was supported by previous studies, in which Meiothermus had a lower optimal temperature growth range $\left(50-60^{\circ} \mathrm{C}\right)$ than Thermus strains $\left(65-75^{\circ} \mathrm{C}\right)[22,39,40]$. T. brockianus was the most abundant species in the four geothermal regions, indicating that this may be a universal culturable Thermus species in southwestern Yunnan Province. A total of 13 strains were found in $2 \mathrm{Dl}$ hot spring samples under 4 isolation temperatures $\left(55,63,70\right.$ and $\left.75^{\circ} \mathrm{C}\right), 11$ strains were found in $2 \mathrm{Lc}$ hot spring samples with isolation temperatures of 70 and $75^{\circ} \mathrm{C}, 9$ strains were found in 3 Bs hot springs with isolation temperatures of 63,70 and $75^{\circ} \mathrm{C}$, and 1 strain was found in a Dh hot spring with an isolation temperature of $75^{\circ} \mathrm{C}$. The optimum isolation temperature of $T$. brockianus was $70-75{ }^{\circ} \mathrm{C}$ (Table 2). The conclusion here was supported by previous studies in which $T$. brockianus was reported to have a broad global distribution across hot springs in Iceland [41,42], Yellowstone National Park in the US [23,43] and the Rehai region of Tengchong County in Yunnan Province, China [28]. T. oshimai is another Thermus species that was isolated from hot springs in Portugal, Iceland and Azores [44], the Great Basin in the US [45] and the Rehai region of Tengchong County in China [27]. In this study, 45 strains, which were isolated from three geothermal regions at an optimum isolation temperature of $63-70{ }^{\circ} \mathrm{C}$, clustered with T. oshimai with $98.87-100 \%$ sequence similarities. These strains dominated in Bs hot springs (31 out of 45) and Lc hot springs (13 out of 45 ) with one strain from the Dl hot springs. Thermus amyloliquefaciens was a recently named Thermus species isolated from the Niujie hot spring of the Dl geothermal region, Yunnan Province, China [19]. In this study, 33 strains from two geothermal regions had $98.03-99.65 \%$ sequence similarities to T. amyloliquefaciens YIM $77409^{\mathrm{T}}$. Thermus amyloliquefaciens was also predominantly isolated from hot springs in the Dl geothermal region, with an optimum isolation temperature of $63-70{ }^{\circ} \mathrm{C}$. Another three isolates were detected in Lc hot springs. Another abundant Thermus species, Thermus thengchongensis, was found in heated soil samples collected in Rehai National Park, Tengchong [17]. By contrast, T. thengchongensis was not detected in Thengchong hot springs in the Bs geothermal region. In this study, 30 strains of $T$. thengchongensis were isolated from the Lc geothermal region, and 20 strains were isolated from the Dh geothermal region with an optimum isolation temperature of $70-75{ }^{\circ} \mathrm{C}$ (Table 2).

In addition to the abundant Thermus species, strains of other Thermus were also detected in this study, such as T. igniterrae, T. arciformis and T. caliditerrae. Thirteen strains (eight from Dh hot springs and five from Lc hot springs) were similar to T. igniterrae (99.65-99.89\% sequence similarities), which were primarily isolated from hot springs in Iceland [46]. Therefore, this study is the first to report that T. igniterrae was isolated from the hot spring samples of Yunnan Province in China with an isolation temperature of $55-75^{\circ} \mathrm{C}$ (Table 2). Five strains (three from Bs hot springs, one from Dh hot springs and one from Lc hot springs) could be classified as T. arciformis with $98.14-99.44 \%$ sequence similarities; this species was isolated from the Tibet hot springs in China [20]. Four strains (three from Bs hot springs and one from Dh hot springs) could be classified as T. caliditerrae, with 98.14-99.44\% sequence similarities. This species was recently isolated from the Tengchong geothermal region of Yunnan province, China [18]. Some other Thermus species were first reported in this study, including seventeen isolates that could not be assigned to any described Thermus species (similarity $<97 \%$ ). These strains formed two clusters in the phylogenetic tree, representing two potential novel species (Thermus sp. 1 and Thermus sp. 2), and strains from the same geothermal region clustered together. The optimum isolation temperature of those strains was $63-70{ }^{\circ} \mathrm{C}$. Sixteen strains from Lc hot springs were related to T. scotoductus (96.1-97.0\% sequence similarities). Thermus scotoductus was found to have a broad global distribution, being detected from hot springs in Iceland [47], South Africa [48], New Mexico [41] and Portugal [49]. One isolate from Bs hot springs formed a single branch, and it was related to T. caliditerrae ( $95.24 \%$ sequence similarity); this isolate may represent a novel species. 


\section{Conclusions}

To isolate the Thermus-like strains, it is necessary to design isolation procedures that can be adapted to isolate this community. In this study, three media and four or five temperatures were selected to isolate culturable Thermus-like strains (Table 1). In total, 223 yellow / red-pigmented colonies of Thermus-like bacteria were obtained from 17 hot spring samples of the four geothermal regions. At $50{ }^{\circ} \mathrm{C}$, only seven Thermus-like strains were isolated, and all seven strains were affiliated with the genus Meiothermus. Another 16 strains belonging to the genus Meiothermus were isolated at 55 and $63^{\circ} \mathrm{C}$. Above $63{ }^{\circ} \mathrm{C}$, no Meiothermus strain was detected (Table 1). In addition, at 55,63 and $75{ }^{\circ} \mathrm{C}, 26$, 59 and 43 Thermus strains were isolated, respectively. The optimum isolation temperature appeared to be $70{ }^{\circ} \mathrm{C}$, and at this isolation temperature, 72 Thermus strains were isolated from the four geothermal regions. The highest Thermus diversity was found at $63{ }^{\circ} \mathrm{C}$, and under this isolation temperature, nine OTUs were detected (Table 2).

The uneven distribution of richness shown by the Venn diagram (Figure 1) indicated that the structure of Thermus-like bacteria might be different among the four geothermal regions. The results of the cluster analysis showed that the samples from the same geothermal region were clustered into the same group in addition to the 16 hot spring samples of the Dl geothermal region. Culturable Thermus-like bacteria in the Dh and Lc geothermal regions had a closer relationship (nearly $24 \%$ Bray-Curtis similarity) relative to the culturable Thermus-like bacteria in the two other geothermal regions (Figure 6), implying that the culturable Thermus-like bacteria had more similar community compositions in the Dh and Lc geothermal regions in comparison with the two other geothermal regions. This result confirmed that the culturable Thermus-like bacteria had a niche preference among the four geothermal regions.

A total of 223 strains of Thermus-like bacteria isolated from the 4 geothermal regions were classified into 2 genera (Meiothermus and Thermus) and 11 species based on the colony color and $16 \mathrm{~S}$ rRNA nucleotide sequence analyses. In this study, most isolates found in three geothermal regions belonged to T. oshimai. Only one species of Thermus, T. brockianus, was the dominant and universal culturable bacteria in all four geothermal regions. This species had different distribution characteristics among the four geothermal regions. In addition, two other species of Thermus, i.e., T. amyloliquefaciens and T. tengchongensis, were dominant culturable bacteria in these geothermal regions.

Supplementary Materials: The following are available online at https:/ /www.mdpi.com/article/10 .3390/d13090455/s1, Table S1: The Thermus-like bacteria in each OTU from four geothermal regions at cutoff 0.03 .

Author Contributions: Writing—review and editing, Y.W.; Funding acquisition, X.C.; Methodology and strain isolation, Y.W. and L.H.; Data analysis, L.H. and C.X.; Data curation, C.L. and W.X. All authors have read and agreed to the published version of the manuscript.

Funding: This research was funded by National Natural Science Foundation of China (NSFC), grant number 31660001, 31660089, 31660042 and 31960220, and the Major Science and Technology Projects of Yunnan Province (digitalization, development and application of biotic resource), grant number 202002AA100007.

Institutional Review Board Statement: Not applicable.

Data Availability Statement: Not applicable.

Acknowledgments: We thank Qin He of Yunnan University for the helping of sample collection. We thank Ruihua You and Yan Liu of Yunnan University for comments on the manuscript.

Conflicts of Interest: The authors declare that they have no conflict of interest.

\section{References}

1. Zhang, C.L.; Ye, Q.; Huang, Z.; Li, W.; Chen, J.; Song, Z.; Zhao, W.; Bagwell, C.; Inskeep, W.P.; Ross, C.; et al. Global occurrence of archaeal amoA genes in terrestrial hot springs. Appl. Environ. Micobiol. 2008, 74, 6417-6426. [CrossRef] 
2. Pearson, A.; Pi, Y.; Zhao, W.; Li, W.; Li, Y.; Inskeep, W.; Perevalova, A.; Romanek, C.; Li, S.; Zhang, C.L. Factors controlling the distribution of archaeal tetraethers in terrestrial hot springs. Appl. Environ. Micobiol. 2008, 74, 3523-3532. [CrossRef]

3. Jiang, H.; Huang, Q.; Dong, H.; Wang, P.; Wang, F.; Li, W.; Zhang, C. RNA-based investigation of ammonia-oxidizing archaea in hot springs of Yunnan Province, China. Appl. Environ. Micobiol. 2010, 76, 4538-4541. [CrossRef]

4. Song, Z.; Zhi, X.; Li, W.; Zhang, C.; Dong, H. Actinobacterial Diversity in Hot Springs in Tengchong (China), Kamchatka (Russia), and Nevada (USA). Geomicrobiol. J. 2009, 26, 256-263. [CrossRef]

5. $\quad$ Song, Z.Q.; Chen, J.Q.; Jiang, H.C.; Zhou, E.M.; Tang, S.K.; Zhi, X.Y.; Zhang, L.X.; Zhang, C.L.L.; Li, W.J. Diversity of Crenarchaeota in terrestrial hot springs in Tengchong, China. Extremophiles 2010, 14, 287-296. [CrossRef] [PubMed]

6. Song, Z.Q.; Wang, F.P.; Zhi, X.Y.; Chen, J.Q.; Zhou, E.M.; Liang, F.; Xiao, X.; Tang, S.K.; Jiang, H.C.; Zhang, C.L.; et al. Bacterial and archaeal diversities in Yunnan and Tibetan hot springs, China. Environ. Microbiol. 2013, 15, 1160-1175. [CrossRef] [PubMed]

7. Pagaling, E.; Grant, W.D.; Cowan, D.A.; Jones, B.E.; Ma, Y.; Ventosa, A.; Heaphy, S. Bacterial and archaeal diversity in two hot spring microbial mats from the geothermal region of Tengchong, China. Extremophiles 2012, 16, 607-618. [CrossRef]

8. Hou, W.; Wang, S.; Dong, H.; Jiang, H.; Briggs, B.R.; Peacock, J.P.; Huang, Q.; Huang, L.; Wu, G.; Zhi, X.; et al. A comprehensive census of microbial diversity in hot springs of Tengchong, Yunnan Province China using 16S rRNA gene pyrosequencing. PLoS ONE 2013, 8, e53350. [CrossRef] [PubMed]

9. Briggs, B.R.; Brodie, E.L.; Tom, L.M.; Dong, H.; Jiang, H.; Huang, Q.; Wang, S.; Hou, W.; Wu, G.; Huang, L.; et al. Seasonal patterns in microbial communities inhabiting the hot springs of Tengchong, Yunnan Province, China. Environ. Microbiol. 2014, 16, 1579-1591. [CrossRef] [PubMed]

10. Ding, J.; He, H.; Zhang, C.; Yu, Y.; Qiu, G. Isolation and characterization of YNTC-1, a novel Alicyclobacillus sentainesis strain. J. Cent. South Univ. Technol. 2008, 15, 508-514. [CrossRef]

11. Ding, J.; Zhang, R.; Yu, Y.; Jin, D.; Liang, C.; Yi, Y.; Zhu, W.; Xia, J. Novel acidophilic, thermophilic iron and sulfur-oxidizing archaeon isolate from a hot spring in Tengchong, Yunnan, China. Braz. J. Microbiol. 2011, 42, 514-525. [CrossRef]

12. Jiang, C.; Liu, Y.; Liu, Y.Y.; Guo, X.; Liu, S.J. Isolation and characterization of ferrous- and sulfur-oxidizing bacteria from Tengchong solfataric region, China. J. Environ. Sci. 2009, 21, 1247-1252. [CrossRef]

13. Zhang, C.M.; Huang, X.W.; Pan, W.Z.; Zhang, J.; Wei, K.B.; Klenk, H.P.; Tang, S.K.; Li, W.J.; Zhang, K.Q. Anoxybacillus tengchongensis sp. nov. and Anoxybacillus eryuanensis sp. nov., facultatively anaerobic, alkalitolerant bacteria from hot springs. Int. J. Syst. Evol. Microbiol. 2011, 61, 118-122. [CrossRef] [PubMed]

14. Zhang, F.; Liu, X.L.; Dong, X.Z. Thermosyntropha tengcongensis sp. nov., a thermophilic bacterium that syntrophically degrades long-chain fatty acids. Int. J. Syst. Evol. Microbiol. 2012, 62, 759-763. [CrossRef] [PubMed]

15. Chen, J.J.; Lin, L.B.; Zhang, L.L.; Zhang, J.; Tang, S.K.; Wei, Y.L.; Li, W.J. Laceyella sediminis sp. nov., a thermophilic bacterium isolated from a hot spring in China. Int. J. Syst. Evol. Microbiol. 2012, 62, 38-42. [CrossRef] [PubMed]

16. Hedlund, B.P.; Cole, J.K.; Williams, A.J.; Hou, W.; Zhou, E.; Li, W.; Dong, H. A review of the microbiology of the Rehai geothermal field in Tengchong, Yunnan Province, China. Geosci. Front. 2012, 3, 273-288. [CrossRef]

17. Yu, T.T.; Yao, J.C.; Ming, H.; Yin, Y.R.; Zhou, E.M.; Liu, M.J.; Tang, S.K.; Li, W.J. Thermus tengchongensis sp. nov., isolated from a geothermally heated soil sample in Tengchong, Yunnan, south-west China. Antonie Leeuwenhoek 2013, 103, 513-518. [CrossRef]

18. Ming, H.; Yin, Y.R.; Li, S.; Nie, G.X.; Yu, T.T.; Zhou, E.M.; Liu, L.; Dong, L.; Li, W.J. Thermus caliditerrae sp. nov., a novel thermophilic species isolated from a geothermal area. Int. J. Syst. Evol. Microbiol. 2014, 64, 650-656. [CrossRef] [PubMed]

19. Yu, T.T.; Ming, H.; Yao, J.C.; Zhou, E.M.; Park, D.J.; Hozzein, W.N.; Kim, C.J.; Wadaan, M.A.; Li, W.J. Thermus amyloliquefaciens sp. nov., isolated from a hot spring sediment sample. Int. J. Syst. Evol. Microbiol. 2015, 65, 2491-2495. [CrossRef]

20. Zhang, X.Q.; Ying, Y.; Ye, Y.; Xu, X.W.; Zhu, X.F.; Wu, M. Thermus arciformis sp. nov., a thermophilic species from a geothermal area. Int. J. Syst. Evol. Microbiol. 2010, 60, 834-839. [CrossRef]

21. Brock, T.D.; Freeze, H. Thermus aquaticus gen. nov. and sp. nov., a nonsporulating extreme thermophile. J. Bacteriol. 1969, 98, 289-297. [CrossRef] [PubMed]

22. da Costa, M.S.; Rainey, F.A.; Nobre, M.F. The genus Thermus and relatives. In The Prokaryotes: A Handbook on the Biology of Bacteria, 3rd ed.; Dworkin, M., Falkow, S., Rosenberg, E., Schleifer, K.H., Stackebrandt, E., Eds.; Springer: New York, NY, USA, 2006; Volume 7, pp. 797-812.

23. Williams, R.A.D.; Smith, K.E.; Welch, S.G.; Micallef, J.; Sharp, R.J. DNA Relatedness of Thermus strains, description of Thermus brockianus sp. nov. and proposal to reestablish Thermus thermophilus (Oshima and Imahori). Int. J. Syst. Bacteriol. 1995, 45, 495-499. [CrossRef]

24. Lioliou, E.E.; Pantazaki, A.A.; Kyriakidis, D.A. Thermus thermophilus genome analysis: Benefits and implications. Microbial. Cell Fact. 2004, 3, 1723-1727.

25. Balkwill, D.L.; Keift, T.L.; Tsukuda, T.; Kostandarithes, H.M.; Onstott, T.C.; Macanaughton, S.; Bownas, J.; Fredrickson, F. Identification of iron-reducing Thermus strains as Thermus scotoductus. Extremophiles 2004, 8, 37-44. [CrossRef] [PubMed]

26. Opperman, D.J.; van Heerden, E. Aerobic Cr(VI) reduction by Thermus scotoductus strain SA-01. J. App. Microbiol. 2007, 103, 1907-1913. [CrossRef]

27. Lin, L.; Chen, C.; Peng, Q.; Ben, K.; Zhou, Z. Thermus rehai sp. nov., isolated from Rehai of Tengchong, Yunnan Province, China. J. Basic Microbiol. 2002, 42, 337-344. [CrossRef]

28. Lin, L.; Zhang, J.; Wei, Y.; Chen, C.; Peng, Q. Phylogenetic analysis of several Thermus strains from Rehai of Tengchong, Yunnan, China. Can. J. Microbiol. 2005, 51, 881-886. [CrossRef] [PubMed] 
29. Guo, C.L.; Wang, T.; Zhu, W.; Zhang, D.H.; Cui, X.L.; Xu, L.H.; Peng, Q. The phylotype of Thermus from the rehai geothermal area, Tengchong China. J. Microbiol. 2003, 41, 152-156.

30. Cui, X.L.; Mao, P.H.; Zeng, M.; Li, W.J.; Zhang, L.P.; Xu, L.H.; Jiang, C.L. Streptimonospora salina gen. nov., sp. nov., a new member of the family Nocardiopsaceae. Int. J. Syst. Evol. Microbiol. 2001, 51, 357-363. [CrossRef]

31. Lane, D.J. 16S/23S rRNA sequencing. In Nucleic Acid Techniques in Bacterial Systematics; Stackebrandt, E., Goodfellow, M., Eds.; Wiley: Hoboken, NJ, USA, 1991; pp. 115-175.

32. Tamura, K.; Stecher, G.; Peterson, D.; Filipski, A.; Kumar, S. MEGA6: Molecular Evolutionary Genetics Analysis Version 6.0. Mol. Biol. Evol. 2013, 30, 2725-2729. [CrossRef]

33. Kimura, M. A simple method for estimating evolutionary rates of base substitutions through comparative studies of nucleotide sequences. J. Mol. Evol. 1980, 16, 111-120. [CrossRef] [PubMed]

34. Saitou, N.; Nei, M. The neighbor-joining method: A new method for reconstructing phylogenetic trees. Mol. Biol. Evol. 1987, 4, $406-425$.

35. Thompson, J.D.; Gibson, T.J.; Plewniak, F.; Jeanmougin, F.; Higgins, D.G. The CLUSTAL_X windows interface: Flexible strategies for multiple sequence alignment aided by quality analysis tools. Nucleic Acids Res. 1997, 25, 4876-4882. [CrossRef]

36. Schloss, P.D.; Handelsman, J. Introducing DOTUR, a computer program for defining operational taxonomic units and estimating species richness. Appl. Environ. Microbiol. 2005, 71, 1501-1506. [CrossRef]

37. McLellan, S.L.; Huse, S.M.; Mueller-Spitz, S.R.; Andreishcheva, E.N.; Sogin, M.L. Diversity and population structure of sewagederived microorganisms in wastewater treatment plant influent. Environ. Microbiol. 2010, 12, 378-392. [CrossRef]

38. Qian, P.; Wang, Y.; Lee, O.O.; Lou, S.C.; Yang, J.; Lafi, F.F.; Al-Suwailem, A.; Wong, T.Y. Vertical stratification of microbial communities in the Red Sea revealed by $16 \mathrm{~S}$ rDNA pyrosequencing. ISME J. 2010, 5, 507-518. [CrossRef]

39. Nobre, M.F.; Trüper, H.G.; da Costa, M.S. Transfer of Thermus ruber (Loginova et al. 1984), Thermus silvanus (Tenreiro et al. 1995), and Thermus chliarophilus (Tenreiro et al. 1995) to Meiothermus gen. nov. as Meiothermus ruber comb. nov., Meiothermus silvanus comb. nov., and Meiothermus chliarophilus comb. nov., respectively, and emendation of the genus Thermus. Int. J. Syst. Bacteriol. 1996, 46, 604-606.

40. Manaia, C.M.; Hoste, B.; Gutierrez, M.C.; Gillis, M.; Ventosa, A.; Kersters, K.; da Costa, M.S. Halotolerant Thermus strains from marine and terrestrial hot springs belong to Thermus thermophilus (ex Oshima and Imahori, 1974) nom. rev. emend. Syst. Appl. Microbiol. 1995, 17, 526-532. [CrossRef]

41. Hudson, J.A.; Morgan, H.W.; Daniel, R.M. Numerical classification of some Thermus isolates from Icelandic hot springs. Syst. Appl. Microbiol. 1987, 9, 218-223. [CrossRef]

42. Sharp, R.J.; Williams, R.A.D. Properties of Thermus ruber strains isolated from Icelandic hot springs and DNA-DNA homology of Thermus ruber and Thermus aquaticus. Appl. Environ. Microbiol. 1988, 54, 2049-2053. [CrossRef] [PubMed]

43. Munster, M.J.; Munster, A.P.; Woodrow, J.R.; Sharp, R.J. Isolation and preliminary taxonomic studies of Thermus strains isolated from Yellowstone National Park, USA. J. Gen. Microbiol. 1986, 132, 1677-1683. [CrossRef] [PubMed]

44. Williams, R.A.D.; Smith, K.E.; Welch, S.G.; Micallef, J. Thermus oshimai sp. nov., isolated from hot springs in Portugal, Iceland, and the Azores, and comment on the concept of a limited geographical distribution of Thermus species. Int. J. Syst. Bacteriol. 1996, 46, 403-408. [CrossRef]

45. Hedlund, B.P.; Mcdonald, A.I.; Lam, J.; Dodsworth, J.A.; Brown, J.R.; Hungate, B.A. Potential role of Thermus thermophilus and T. oshimai in high rates of nitrous oxide $\left(\mathrm{N}_{2} \mathrm{O}\right)$ production in $80^{\circ} \mathrm{C}$ hot springs in the US Great Basin. Geobiology 2011, 9, 471-480. [CrossRef]

46. Chung, A.P.; Rainey, F.A.; Valente, M.; Nobre, M.F.; da Costa, M.S. Thermus igniterrae sp. nov. and Thermus antranikianii sp. nov., two new species from Iceland. Int. J. Syst. Evol. Microbiol. 2000, 50, 209-217. [CrossRef] [PubMed]

47. Kristjánsson, J.K.; Hjöleifsdóttir, S.; Marteinsson, V.; Alfredsson, G.A. Thermus scotoductus, sp. nov., a pigment-producing thermophilic bacterium from hot tap water in Iceland and including Thermus sp. X-1. Syst. Appl. Microbiol. 1994, 17, 44-50. [CrossRef]

48. Kieft, T.L.; Fredrickson, J.K.; Onstott, T.C.; Gorby, Y.A.; Kostandarithes, H.M.; Bailey, T.J.; Kennedy, D.W.; Li, S.W.; Plymale, A.E.; Spadoni, C.M.; et al. Dissimilatory reduction of Fe (III) and other electron acceptors by a Thermus isolate. Appl. Environ. Microbiol. 1999, 65, 1214-1221. [CrossRef] [PubMed]

49. Santos, M.A.; Williams, R.A.D.; da Costa, M.S. Numerical taxonomy of Thermus isolates from hot springs in Portugal. Syst. Appl. Microbiol. 1989, 12, 310-315. [CrossRef] 